\title{
A Two-Component Regulatory System, pehR-pehS, Controls Endopolygalacturonase Production and Virulence in the Plant Pathogen Erwinia carotovora subsp. carotovora
}

\author{
Diana Flego, ${ }^{1}$ Reet Marits, ${ }^{2}$ Anders R. B. Eriksson, ${ }^{1}$ Viia Kõiv, ${ }^{2}$ Maj-Brit Karlsson, ${ }^{1}$ \\ Riikka Heikinheimo, ${ }^{1}$ and E. Tapio Palva ${ }^{3}$ \\ ${ }^{1}$ Department of Plant Biology, Uppsala Genetic Center, Swedish University of Agricultural Sciences, Box \\ 7080, S-75007 Uppsala, Sweden; ${ }^{2}$ Institute of Molecular and Cell Biology, Tartu University, 23 Riia \\ Street, 51010 Tartu, Estonia; ${ }^{3}$ Viikki Biocenter, Department of Biosciences, Division of Genetics, and \\ Institute of Biotechnology, Box 56, FIN-00014, University of Helsinki, Finland \\ Accepted 16 December 1999.
}

Genes coding for the main virulence determinants of the plant pathogen Erwinia carotovora subsp. carotovora, the plant cell wall-degrading enzymes, are under the coordinate control of global regulator systems including both positive and negative factors. In addition to this global control, some virulence determinants are subject to specific regulation. We have previously shown that mutations in the pehR locus result in reduced virulence and impaired production of one of these enzymes, an endopolygalacturonase (PehA). In contrast, these pehR strains produce essentially wild-type levels of other extracellular enzymes including pectate lyases and cellulases. In this work, we characterized the pehR locus and showed that the DNA sequence is composed of two genes, designated pehR and pehS, present in an operon. Mutations in either pehR or pehS caused a Peh-negative phenotype and resulted in reduced virulence on tobacco seedlings. Complementation experiments indicated that both genes are required for transcriptional activation of the endopolygalacturonase gene, $p e h A$, as well as restoration of virulence. Structural characterization of the pehR-pehS operon demonstrated that the corresponding polypeptides are highly similar to the two-component transcriptional regulators PhoP-PhoQ of both Escherichia coli and Salmonella typhimurium. Functional similarity of PehR-PehS with PhoP-PhoQ of E. coli and S. typhimurium was demonstrated by genetic complementation.

The plant-pathogenic enterobacterium Erwinia carotovora subsp. carotovora belongs to the soft-rot group of erwinias

Corresponding author: E. Tapio Palva; Telephone: +358-9-191 59600; Fax: +358-9-191 59076; E-mail: Tapio.Palva@helsinki.fi

Present address of Riikka Heikinheimo: TEKES, Box 69, FIN-00101 Helsinki, Finland.

Diana Flego and Reet Marits contributed equally to this paper.

Nucleotide and/or amino acid sequence data have been submitted to the GenBank data base as accession number AF022772. and has the ability to infect a number of plant species, including several economically important crops. These bacteria secrete a large arsenal of plant cell wall-degrading enzymes, causing maceration of different plant organs and tissues (Pérombelon and Kelman 1980; Collmer and Keen 1986; Barras et al. 1994). The crucial role of these extracellular enzymes in virulence is demonstrated by isolation of avirulent mutants that are defective either in enzyme production (exp mutants; Pirhonen et al. 1991, 1993) (aep mutants; Murata et al. 1991, 1994; Liu et al. 1993) (rex mutants; Jones et al. 1993) or in secretion of the enzymes (out mutants) (Andro et al. 1984; Ji et al. 1987; Pirhonen et al. 1991; Thurn and Chatterjee 1985).

The production of these extracellular enzymes is coordinately controlled by a number of global regulators. A central control in this regulatory network is exerted by the cell density-dependent accumulation of a diffusible signal molecule, N-(3-oxohexanoyl)-L-homoserine lactone (OHHL), the $E$. carotovora autoinducer (Jones et al. 1993; Pirhonen et al. 1993). In addition to the expI gene directing the synthesis of OHHL, other global regulatory genes required for extracellular enzyme production and virulence have been characterized. These include $\exp A$ and $\exp S$ encoding proteins of the twocomponent regulator family (Pirhonen et al. 1993; Eriksson et al. 1998), as well as aepA and aepH (rsmB) (Liu et al. 1993; Murata et al. 1994; Liu et al. 1998). However, not only is the synthesis of virulence determinants controlled by the positive factors discussed above, but also a negative global regulator (RsmA) has been described (Chatterjee et al. 1995; Cui et al. 1995; Mukherjee et al. 1996; Liu et al. 1998).

In addition to global regulators, specific regulators, which can modify the expression of one gene or a subset of genes, are also involved in controlling the production of extracellular enzymes. In a related pathogen, Erwinia chrysanthemi, differential expression of genes for pectate lyases (Pels) has been observed in different hosts (Beaulieu et al. 1993) and even in different tissues of the same host (Lojkowska et al. 1993). Some Pel isoforms are produced only during infection in planta (Kelemu and Collmer 1993). 
We have previously characterized mutants of E. carotovora subsp. carotovora that are impaired in the production of an endopolygalacturonase (PehA) but that produced and secreted Pels and cellulases (Cels) at the wild-type level (Saarilahti et al. 1992). The mutation was shown to affect transcriptional activation of the endopolygalacturonase gene, pehA. This suggested that the mutated locus, designated pehR, could encode a specific regulator of PehA. Mutations in pehR, as well as in the structural gene, pehA, exhibited a similar reduction in virulence on in vitro grown tobacco seedlings (Saarilahti et al. 1992). In this work we show that the pehR locus contains an operon of two genes, designated pehR and pehS, both of which are required for pehA expression and virulence. We also show that PehR-PehS is both structurally and functionally related to the two-component regulatory system PhoP-PhoQ that controls several pathogenicity properties of Salmonella typhimurium and Escherichia coli.

\section{RESULTS}

\section{The pehR locus contains an operon of two genes.}

For molecular characterization of the pehR locus we first cloned the transposon mutant allele present in strain SCC1935 of E. carotovora subsp. carotovora. The relevant clone was obtained by selecting for the kanamycin resistance provided by the transposon. Partial sequencing of the clone, carrying a 3.2-kb SalI-EcoRI fragment of chromosomal origin, was established and used to design oligonucleotide primers for polymerase chain reaction (PCR) amplification of the wild-type allele. Structural characterization of the pehR locus revealed two complete open reading frames (ORFs), apparently present as an operon (Fig. 1; GenBank accession number AF022772). The first 684-bp ORF, identified as pehR, is located between nucleotides 253 and 936. This ORF contained the original transposon insertion at 88 nucleotides (nt) downstream from the start codon (Fig. 1). The second 1,455-bp ORF, designated pehS, is located between nucleotides 933 and 2387. Both pehR and pehS coding regions begin with an ATG codon and end with a TGA codon. The start codon of pehS overlaps the stop codon of pehR by $2 \mathrm{nt}$, suggesting translational coupling commonly seen with two-component regulators (Govantes et al. 1998). A Shine-Dalgarno sequence, GAGGA, precedes the ATG codon of pehR by $7 \mathrm{nt}$; the pehS gene has a sequence AGG 6 nt upstream of the start codon. A putative -10 sequence, GATAAT, is found at nucleotides 125 to 130 . The -35 region is replaced by a similar direct hexanucleotide repeat sequence GTTTA(T or C) as originally characterized in the phoP promoter (Soncini et al. 1995). Sequences that may form stem-loop structures and function as transcriptional terminators can be found $134 \mathrm{nt}$ upstream of pehR and $82 \mathrm{nt}$ downstream of the termination codon of pehS.

\section{Both pehR and pehS mutants are affected in the production of endopolygalacturonase and exhibit reduced virulence.}

We first wanted to assess the role of the individual genes at the pehR locus, pehR and pehS, on virulence and production of extracellular enzymes. To characterize the contribution of the pehS gene, we constructed a pehS insertion mutant (SCC4194) by marker exchange. Comparison of the extracel- lular enzyme phenotypes of SCC1935 and SCC4194 showed that they were rather similar. Neither of the mutants produced measurable amounts of polygalacturonase (Fig. 2) but secreted both Pels and Cels close to the wild-type levels (not shown). Northern (RNA) blot analysis of pehA expression demonstrated that both mutants failed to accumulate detectable amounts of pehA mRNA (Fig. 2).

Virulence tests with in vitro grown tobacco seedlings showed that both mutants exhibit reduced virulence (Table 1). The reduced virulence phenotype of the pehR mutant SCC1935 was similar to that of a pehA mutant (SCC4080), but the pehS mutant SCC4194 appeared to be even less virulent.

For complementation analysis, the genomic fragment harboring the wild-type alleles of both pehR and pehS was first cloned into pBluescript to obtain plasmid pREM100 (Fig. 1). To facilitate the reliability of the complementation, the $2.5-\mathrm{kb}$ fragment carrying pehR-pehS was incorporated into the low copy number vector pMW118. The resulting plasmid, pREM200, and its mutant derivatives, pREM201 (pehR mu-

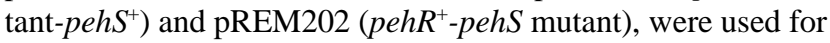
the actual complementation experiments. The mutation introduced into pehR (in pREM201) was a 2-bp deletion at the $N d e$ I cleavage site resulting in a frameshift. The pehS mutant allele (in pREM202) harbored an 859-bp deletion (from MluI to $S p h \mathrm{I}$ ). Introduction of pREM200 to the mutants restored the $\mathrm{Peh}^{+}$phenotype to both SCC1935 and SCC4194. In contrast, the mutant plasmids pREM201 and pREM202 only comple-

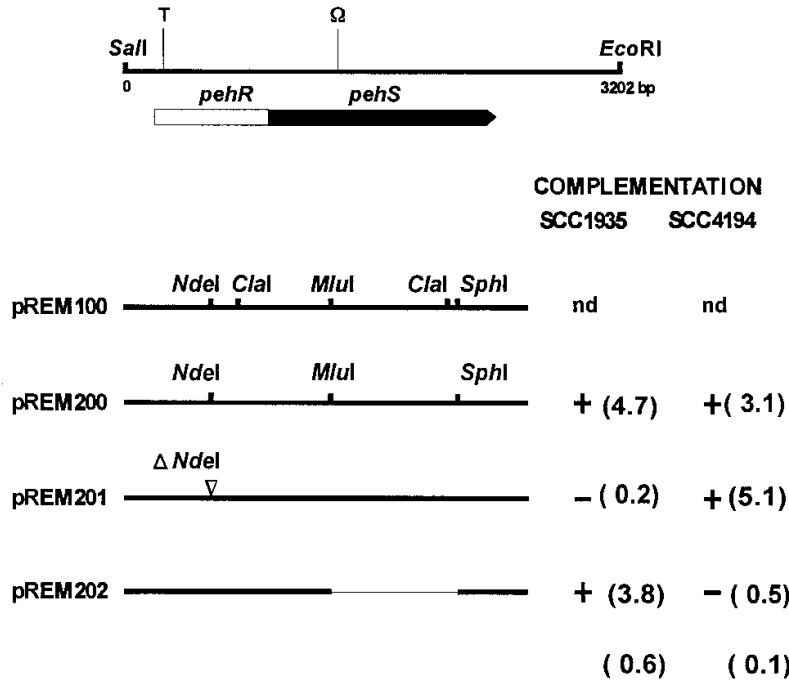

Fig. 1. The organization of the SalI-EcoRI chromosomal fragment containing the pehR-pehS operon and plasmid constructs derived from this region. Location of transposon insertion in the pehR gene of SCC1935 and location of interposon $\Omega_{\mathrm{Cm}}$ in the pehS gene of SCC4194 are indicated by $\mathrm{T}$ and $\Omega$, respectively. The pehR and pehS open reading frames, determined by sequencing, are shown by an open bar and filled bar, respectively. $\Delta N d e$ I shows position of the 2-bp deletion in the pehR gene on pREM201. Restriction enzymes $M l u \mathrm{I}$ and $S p h \mathrm{I}$ were used to delete a 859-bp fragment (thin line) from the pehS gene on pREM202. Complementation of the pehR mutation in SCC1935 and the pehS mutation in SCC4194, determined by Northern (RNA) hybridization and assay of Peh activity, is indicated by + or - , respectively. nd, not determined. The measured Peh activity is shown in parentheses. Nucleotide sequence of the pehR-pehS operon of Erwinia carotovora subsp. carotovora will appear in the GenBank data base under accession number AF022772. 
mented the pehS and pehR mutants, respectively (Fig. 1). The plasmid pREM201, carrying a frameshift-mutated pehR gene but an intact pehS gene, could not complement the pehR mutant SCC1935, but restored the $\mathrm{Peh}^{+}$phenotype to the pehS mutant SCC4194. The plasmid pREM202, carrying an intact pehR gene and a deletion of the pehS gene, failed to restore the $\mathrm{Peh}^{+}$phenotype to the pehS mutant SCC4194 as expected but complemented the pehR mutant SCC1935 (Fig. 1). This was unexpected since the transposon insertion in pehR should be polar.

A more extensive complementation analysis by Northern hybridization and enzyme assays showed that pREM200 restores pehA expression and Peh activity to both pehR (SCC1935) and pehS (SCC4194) mutants. The enzyme activity obtained in both backgrounds by the complementing clone was about $35 \%$ of the wild-type level (Fig. 2). Furthermore, we assessed the effect of this plasmid on virulence. The results (Table 1) showed that while pREM200 was able to restore the virulence of SCC1935 to wild-type level, the virulence of SCC4194 was only partially restored.

Taken together, these results indicate that both $p e h R$ and $p e h S$ are required for pehA expression and that the pehR-pehS operon controls polygalacturonase production and virulence in E. carotovora subsp. carotovora.
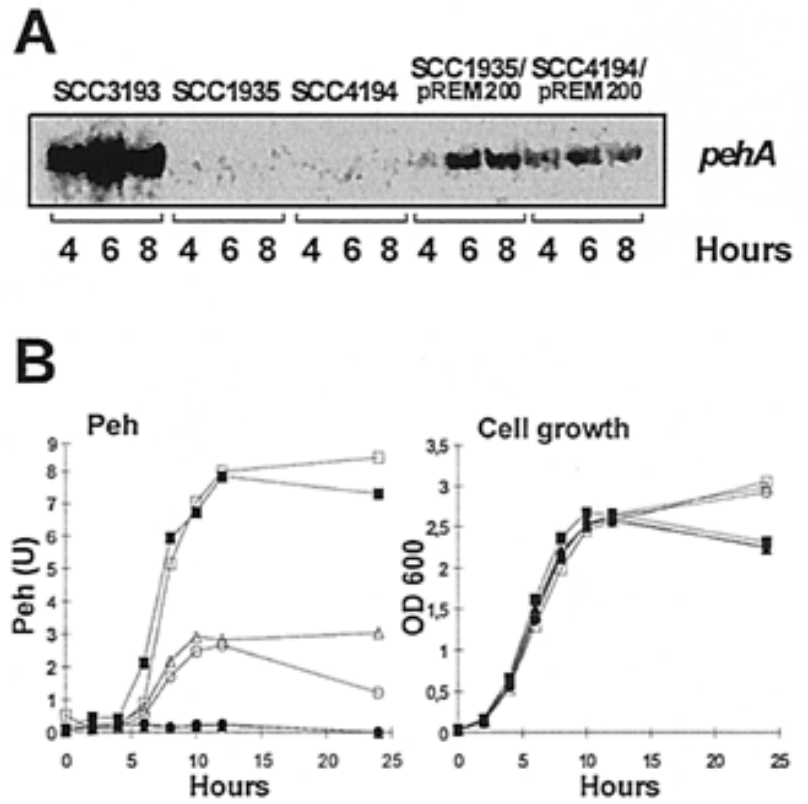

Fig. 2. Effect of the pehR and pehS mutations on pehA expression and production of polygalacturonase (Peh) and complementation of the mutants by a pehR-pehS clone. A, Northern (RNA) blot analysis of pehA expression in Erwinia carotovora subsp. carotovora wild-type SCC3193, pehR mutant SCC1935, pehS mutant SCC4194, and mutants carrying the complementing plasmid pREM200 (pehR ${ }^{+}$-peh $\left.S^{+}\right)$. Accumulation of RNA was followed during growth and samples were collected at indicated time points. Each lane contains $5 \mu \mathrm{g}$ of total RNA. The pehA probe was prepared from an 1.2-kb internal EcoRV fragment from the pehA gene in pHSK24. B, Peh activity in the same strains, including the wild-type strain SCC3193 carrying the vector plasmid pMW118. The strains are indicated as follows: SCC3193 (ם),

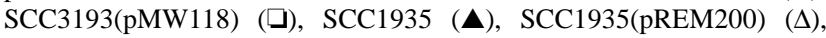
SCC4194 (O), SCC4194(pREM200) (O). C, Corresponding growth curves; strains were grown in $\mathrm{L}$-medium supplemented with appropriate antibiotics at $28^{\circ} \mathrm{C}$
PehR and PehS are structurally similar to the two-component regulators PhoP and PhoQ of $E$. coli and $S$. typhimurium.

The ORFs of pehR and pehS code for polypeptides of 227 and 484 amino acids with calculated molecular masses of 26 and $55 \mathrm{kDa}$, respectively. When protein data bases were searched with the deduced amino acid sequences of the PehR and PehS polypeptides, they were found to be similar to the two-component regulatory system PhoP-PhoQ of $E$. coli (Kasahara et al. 1992) and S. typhimurium (Miller et al. 1989). The putative response regulators PehR of E. carotovora subsp. carotovora and PhoP of $E$. coli and $S$. typhimurium share identity throughout the whole amino acid sequence. The amino acid identity of PehR with PhoP of $E$. coli is $76.2 \%$ and with PhoP of S. typhimurium is $74.6 \%$. The crucial regions for phosphorylation as well as the putative DNA binding region are very well conserved (Fig. 3). The PehS protein is highly similar to the PhoQ proteins of E. coli and $S$. typhimurium, which belong to the histidine kinase family. The amino acid identity between PehS and the PhoQ sensor kinase of E. coli and S. typhimurium is 58.6 and $57.4 \%$, respectively (Fig. 3B). In PehS, the two hydrophobic transmembrane segments are very well conserved (amino acids 16 to 42 and 188 to 216). In contrast, the sequence between them, which by similarity would correspond to the periplasmic loop (Miller et al. 1989) is the part of the polypeptide that differs most. An additional feature that relates PehS to the sensor kinase family is a sequence (amino acids 269 to 277) and a histidine residue (amino acid 275) positioned similarly to those involved in CheA (Hess et al. 1988) and nitrogen regulator $\mathrm{I}\left(\mathrm{NR}_{\mathrm{I}}\right)$ autophosphorylation (Weiss and Magasanik 1988), respectively. Together, these comparisons demonstrate the close structural similarity of the PehR and PehS polypeptides to the two-component regulator PhoP-PhoQ of E. coli and S. typhimurium and indicate that pehR-pehS encodes a two-component regulator system.

In addition to the homology of the pehR-pehS and phoP$p h o Q$ genes, the flanking regions also appeared similar. The pehR gene is preceded by a short ORF encoding the C terminus of adenylosuccinate lyase; the ORF distal to pehS encodes the YcfD hypothetical protein. This organization is similar to that of the phoP-phoQ flanking regions from E. coli $\mathrm{K} 12$ as characterized by Kasahara and co-workers (1992).

Table 1. Virulence of pehR and pehS mutants on axenic tobacco (Nicotiana tabacum cv. Samsun) seedlings and complementation of mutants

\begin{tabular}{|c|c|c|c|}
\hline \multirow[b]{2}{*}{ Strain } & \multirow[b]{2}{*}{ Genotype } & \multicolumn{2}{|c|}{ Virulence } \\
\hline & & $\begin{array}{c}\text { Plants } \\
\text { infected }^{\mathrm{a}}\end{array}$ & $\%$ \\
\hline SCC3193 & Wild type & $71 / 72$ & 98 \\
\hline SCC1935 & pehR mutant & $16 / 72$ & 22 \\
\hline SCC4194 & pehS mutant & $5 / 72$ & 7 \\
\hline SCC4080 & pehA mutant & $17 / 72$ & 23 \\
\hline SCC3193 pMW118 & Wild type & $37 / 48$ & 77 \\
\hline SCC1935 pMW118 & pehR mutant & $0 / 24$ & 0 \\
\hline SCC1935 pREM200 & 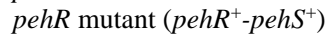 & $18 / 24$ & 75 \\
\hline SCC4194 pMW118 & pehS mutant & $0 / 24$ & 0 \\
\hline SCC4194 pREM200 & pehS mutant $\left(\right.$ pehR $\left.R^{+}-p e h S^{+}\right)$ & $9 / 24$ & 37 \\
\hline
\end{tabular}

${ }^{a}$ Results show ratio of plants infected to those inoculated. 


\section{PehR-PehS is functionally related to PhoP-PhoQ}

\section{of $E$. coli and $S$. typhimurium.}

The structural similarity of PehR-PehS of E. carotovora subsp. carotovora and PhoP-PhoQ of E. coli and $S$. typhimurium prompted us to test whether they were also functionally related. To this end, we transferred a plasmid (pDFL2) harboring a pehA-lacZ transcriptional fusion to the E. coli wild-type (with respect to PhoP-PhoQ) strain MC4100 and to its phoP mutant FS1002 and measured $\beta$-galactosidase activity. As a control, the $\beta$-galactosidase activity from pDFL2 was measured in the E. carotovora subsp. carotovora wild-type strain SCC3193, the pehR mutant SCC1935, and the pehS mutant SCC4194. As expected, $\beta$-galactosidase activity was almost abolished in the pehR and pehS mutants, compared with the activity found in the E. carotovora subsp. carotovora wild-type SCC3193 (Fig. 4). Interestingly, the $\beta$-galactosidase activity in the E. coli wild-type strain MC4100 was relatively high, about $42 \%$ of the activity in E. carotovora subsp. carotovora wild type, showing that $E$. coli can support the expression of the pehA gene. This activity was abolished in the phoP mutant FS1002, indicating that intact phoP is required for pehA expression in E. coli. Our previous work (Flego et al. 1997) has indicated that calcium regulation of pehA is mediated by pehR. Similarly, the PhoP-PhoQ system is involved in

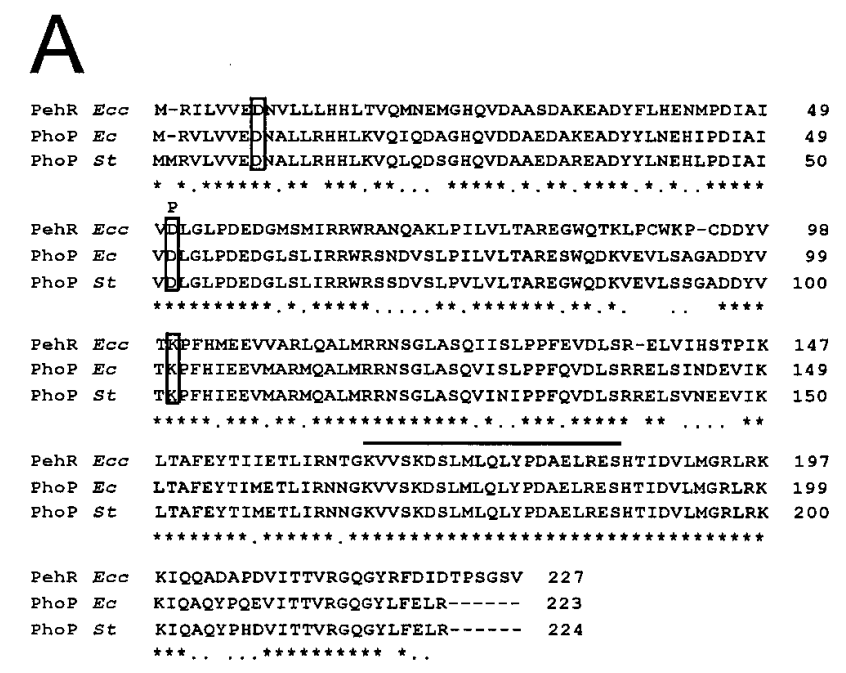

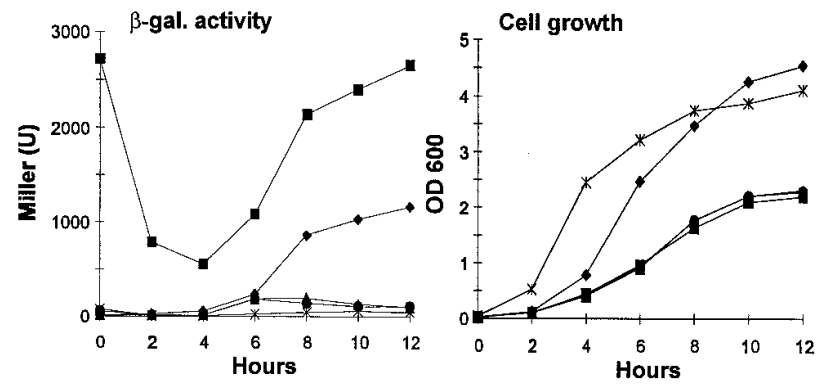

Fig. 4. PhoP-dependent expression of pehA in Escherichia coli. A, $\beta$ Galactosidase activity of pDFL2 carrying transcriptional pehA-lacZ fusion was determined in E. coli strains MC4100 (wild type) and FS1002 (phoP mutant), Erwinia carotovora subsp. carotovora strains SCC3193 (wild type), SCC1935 (pehR mutant), and SCC4194 (pehS mutant). The strains are indicated as follows: SCC3193(pDFL2) (苂, SCC1935(pDFL2) (४), SCC4194(pDFL2) (•), MC4100(pDFL2) (•), FS1002(pDFL2) (*). B, Corresponding growth curves; strains were grown in L medium supplemented with ampicillin, E. coli strains were grown at $37^{\circ} \mathrm{C}$ and E. carotovora subsp. carotovora strains at $28^{\circ} \mathrm{C}$.

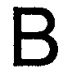

PehS ECC PhoQ EC

Pehs EaC PhoQ EC
PhoQ St

Pehs ECC

Phod EC
Phod St

Pehs EcC

PhoQ EC
PhoQ St

Pehs ECC

PhoQ EC

PhoQ st

Pehs ECC PhoQ EC

Phod $s t$

Pehs Ece PhoQ EC
Phod st

PehS ECC PhoQ Ec
Phoo St

Pehs EcC PhoQ $E$

Pehs EcC

Pehs Eco

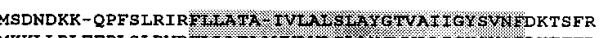

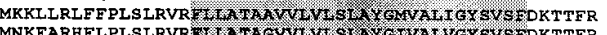

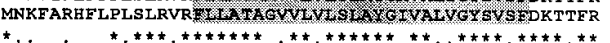
LLRGESNLYYSLAQWRDNQLNIVTPPDVDINFPTLVLIYDEQGNMLWREK LIRGE SNLFY TLAKWENNKL HVEL PENIDKOS PTMTLIYDENGQLLWAQR 10 LLRGESNLFYTLAKWENNKI SVELPENLRMOS PTMTLIYDETGKLLWTOR 100

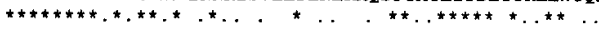

HVPELEALIKPEWLNK TAYHELDTDSDT SSAVLTGNTLLISSLRALNGTO DVPWLMKMIQPDWLKSNGFHEIEADVNDTSLLLSGDHSIQQQLQEVREDD 150 NIPWLIKSIQPEWLKTNGFHEIETNVDA TSTLLSEDHSAQEKLKEVREDD 150

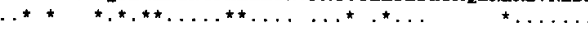
NNA-LTHSIAVN-VYPRTEHLPSITIVVDRIPQEIQQEDVWWWWWRXVF DDAEMTHSVAVN-VY PATSRMPKLTIVVVDTI PVELKSSYLVWSWRTVW: 196

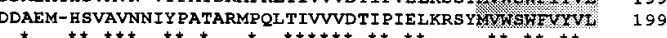

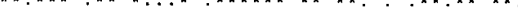

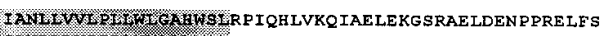

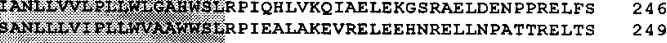
AMULWWELEWLE MUSTRPIEALAREVRELEDH HREMLNPETTRELTS 249

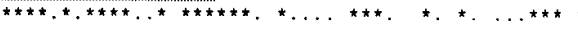
LVKNINILLNNE RORYHKYR TLTDLTHST TTT-GVLQTTLRALRTGKEI 298

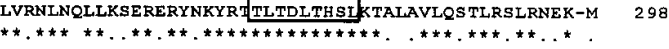
TVSDA SVSDAE PVMLEQISRISQQI GYYLHRASMRG -GTLLSRELH PVAPLLDNL SVSKAE PVMLEQISRISQQIGYYLHRASMRGSGVLLSRELHPVAPILDNL

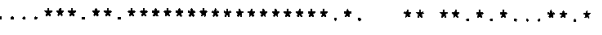
CSALNKVYQRKGVVLTLDIPPELTTVGE KNDFMEVMGNILDNACKYCLEF TSALNKVYQRKGVNISLDISPEISFVGE QNDFVEVMGNVIDNACKYCLEF ISALNKVYQRKGVNI SMDIS PE ISFVGE ONDFVEVMGNVLDNACKYCLEF

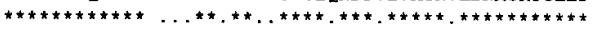

VEISVOYSDHKLHLIIDDDGPGILESKREVIFQRGQRADRMRPGQGIGLA VEISARQTDEHLYIVVEDDGPGIPLSKREVIFDRGQRVDTLRPGQGVGLA

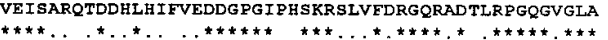
$\begin{array}{lll}\text { VAREITEQYEGXIVAGESMLGGARMEVIFGRQHSAPKDE } & 486 \\ \text { VAREITEOYAGQIIASDSLIGGARMEVVFGROHPTOKEE } & 487\end{array}$ VAREI TEQYAGQI IASDSLIGGGARMEVVFGROHPTQKE

Fig. 3. Amino acid alignment of PehR-PehS of Erwinia carotovora subsp. carotovora (Ecc) with PhoP-PhoQ of Escherichia coli (Ec) and Salmonella typhimurium (St). Alignment of (A) response regulators (PehR and PhoP) and (B) sensor kinases (PehS and PhoQ). Highly conserved amino acid residues in response regulator family are boxed. A potential phosphorylation site is indicated by P; a putative DNA binding domain by overlining. Hydrophobic transmembrane segments in PehS and PhoQ are highlighted by a shaded rectangle; putative autophosporylation site is boxed. $*=$ identical and "." = similar amino acids. 
divalent cation (including $\mathrm{Mg}^{2+}$ and $\mathrm{Ca}^{2+}$ ) controlled expression of a number of genes in E. coli and S. typhimurium (García-Véscovi et al. 1996). To test whether the PhoP-PhoQ system was also involved in $\mathrm{Ca}^{2+}$ control of pehA expression, we characterized the expression of a pehA-lacZ fusion in both wild-type (MC4100) and phoP (FS1002) strains of E. coli. The results of this analysis (Table 2) demonstrate the presence of $\mathrm{Ca}^{2+}$ regulation of pehA in E. coli and show that this regulation is abolished in the phoP mutant, suggesting that $\mathrm{PhoP}$ is a functional analogue of PehR also in this respect.

PhoP of $S$. typhimurium was originally discovered as a transcriptional regulator of nonspecific acid phosphatase (NSAP). Both $p h o P$ and $p h o Q$ mutants lack NSAP activity. To assess whether pehR-pehS is able to complement the NSAP-negative phenotype of the $p h o P$ and $p h o Q$ mutants we transferred

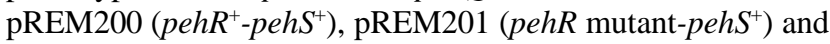
pREM202 (pehR ${ }^{+}$-pehS mutant) to the phoP mutant strain MS7953s and to the $p h o Q$ mutant strain MS5996s. The $S$. typhimurium wild-type strain ATCC14028s containing the vector pMW118 was used as a control. Strains were grown on phosphorus free M121 medium plates supplemented with 50 $\mathrm{mM} \mathrm{KH} \mathrm{KO}_{4}$ and stained for NSAP activity (Fig. 5). The

Table 2. Effect of PhoP on the calcium modulated expression of pehA in Escherichia coli

\begin{tabular}{lcc}
\hline & \multicolumn{2}{c}{$\beta$-Galactosidase activity } \\
\cline { 2 - 3 }$\left[\mathbf{C a C l}_{2}\right]$ & $\mathbf{M C 4 1 0 0}$ & $\mathbf{F S 1 0 0 2}($ phoP $)$ \\
\hline $0 \mathrm{mM}$ & 4,665 & 76 \\
$10 \mathrm{mM}$ & 288 & 73 \\
\hline
\end{tabular}

${ }^{a}$ Both strains harbored a plasmid-borne pehA-lacZ transcriptional fusion. The $\beta$-galactosidase activity assayed after $8 \mathrm{~h}$ of growth is given in Miller units.

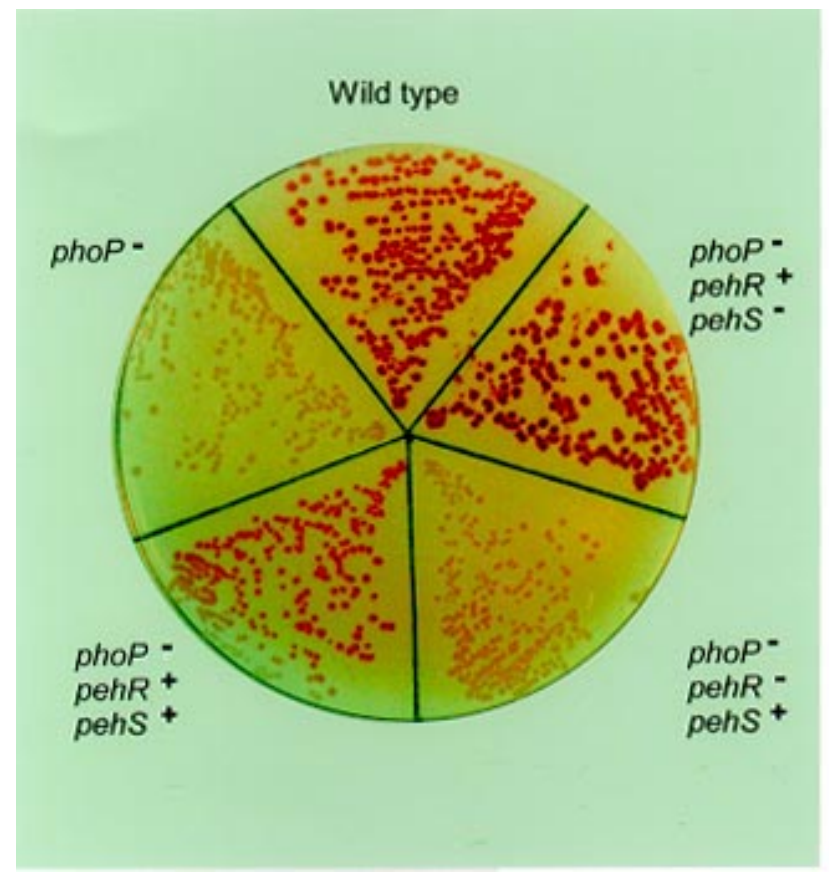

phoP mutant MS7953s was clearly complemented by plasmids carrying an intact pehR gene, pREM200 (pehR $R^{+}$-peh $\left.S^{+}\right)$ and pREM202 (pehR $R^{+}$-pehS mutant). Both plasmids restored the NSAP-positive phenotype to the phoP mutant. In contrast, the pREM201 plasmid (pehR mutant-peh $S^{+}$) carrying a frameshift mutation in the pehR gene could not restore NSAP activity to the phoP mutant (Figs. 5 and 1). The $p h o Q$ sensor kinase mutant MS5996s was complemented by the plasmids carrying the pehS wild-type allele, pREM200 and pREM201. Surprisingly, NSAP activity was restored even by pREM202, which contains an intact pehR gene but a deletion in the pehS gene (Fig. 5). This is in contrast to the results in E. carotovora subsp. carotovora, where the pehS sensor mutant SCC4194 was complemented only by plasmids containing the intact pehS gene (Fig. 1).

It appears that E. carotovora subsp. carotovora does not produce NSAP activity. Staining of E. carotovora subsp. carotovora wild type (SCC3193) and both mutants (SCC1935 and SCC4194) for NSAP activity on induced and non-induced conditions did not give any positive reaction. All three strains have regulated phosphatase activity toward p-nitrophenyl phosphate (data not shown).

In conclusion, these data showing PhoP-dependent expression of an pehR-pehS controlled target gene pehA in E. coli and complementation of $p h o P$ and $p h o Q$ mutants by pehRpehS in S. typhimurium demonstrate that PehR-PehS is functionally similar to the two-component regulator system PhoPPhoQ in these bacteria.

\section{DISCUSSION}

The E. carotovora subsp. carotovora wild-type strain SCC3193 produces a number of extracellular plant cell wall-

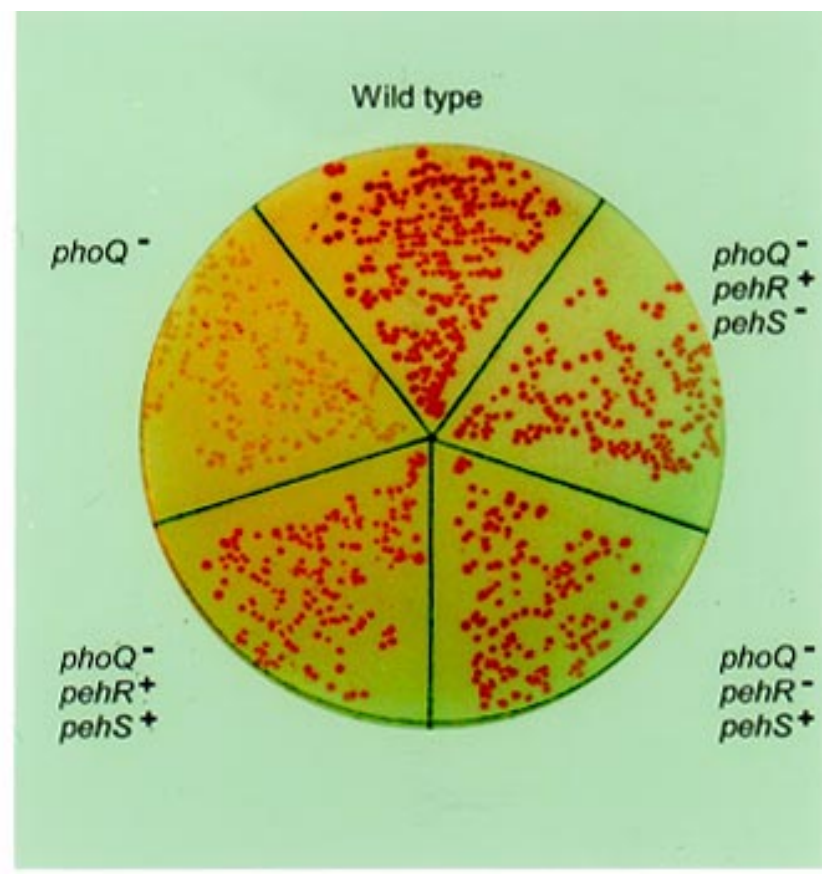

Fig. 5. Complementation of nonspecific acid phosphatase (NSAP) negative phenotype of phoP and phoQ mutants of Salmonella typhimurium by pehRpehS of Erwinia carotovora subsp. carotovora. The S. typhimurium wild-type strain ATCC14028s carrying the vector plasmid pMW118, and its trans-

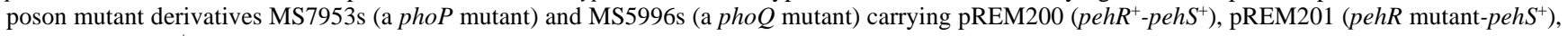
pREM202 (pehR ${ }^{+}$-pehS mutant), or pMW118 were stained for NSAP activity. Cells producing NSAP are red. 
degrading enzymes: an endopolygalacturonase (encoded by pehA), at least four Pels (encoded by pelA to pelD) and two Cels (encoded by celC, celVI) (Saarilahti et al. 1990; Heikinheimo et al. 1995; Mäe et al. 1995). All of these virulence genes including pehA are controlled by at least two global regulatory systems, quorum sensing (Pirhonen et al. 1993) and the two-component regulator ExpA-ExpS (Eriksson et al. 1998). In addition to these global controls, the pehA gene seems to be specifically controlled by the pehR locus, in contrast to the other major virulence genes.

In this paper, we describe the molecular characterization of the pehR locus. By DNA sequence analysis we show that the locus contains two ORFs. The genes designated pehR and pehS appear to form an operon with pehR being the promoter proximal gene. Analysis of the deduced amino acid sequences suggests that PehR and PehS are members of a twocomponent regulator system, PehS being the sensor kinase and PehR the response regulator. The evidence for the two proteins belonging to the same regulator system comes partly from the structural organization of corresponding genes as an operon, a usual arrangement for cognate partners of twocomponent systems, and partly from the phenotypic analysis of pehR and pehS mutants. Our experiments indicated that both pehR and pehS are required for pehA expression and virulence. Mutations in either of the genes resulted in a Pehnegative phenotype and reduced virulence. The mutations could be complemented by introduction of the respective wild-type alleles on low copy plasmids restoring both pehA expression and virulence. Surprisingly, even the plasmid pREM202 (pehR $R^{+}$-pehS mutant) restored Peh activity to the pehR mutant SCC1935, which has a transposon insertion in the pehR gene and should be polar on pehS. It is possible that the increased amount of PehR is sufficient to activate transcription of pehA in the absence of PehS phosphorylation. Alternatively, the increased PehR concentration could stimulate unspecific phosphorylation. A third possibility is that pehS, in addition to being co-transcribed with pehR, has its own promoter, leading to low level production of PehS in the pehR mutant SCC1935.

The observed effect on virulence of pehR or pehS mutants could be explained by their effect on PehA production. Inactivation of pehA alone results in reduced virulence (Saarilahti et al. 1992; Flego et al. 1997). The reduced virulence phenotypes of pehA, pehR, and pehS mutants are similar (Table 1) and the phenotypes of pehA and pehR mutants could not be distinguished. Interestingly, the pehS mutant appeared in repeated tests to be even less virulent. Introduction of the pehR-pehS clone restored the Peh activity to both mutants. This activity was apparently sufficient for pehR mutant to reach the virulence of wild type, while virulence of pehS mutant was only partially restored. Currently, we can only speculate about this difference between the phenotypes of pehR and pehS mutants. Although in many cases a specific sensor kinase-response regulator pair may function as the primary regulator of a particular response, other kinases and regulators could potentially influence each of the components. Evidence for cross-talk in vivo has consistently been seen in mutants that lack a given kinase. It has been also shown that certain low-molecularweight phosphorylated compounds such as phosphoramidate, carbamyl phosphate, and acetyl phosphate can transfer phosphoryl groups to the response regulator in the absence of a kinase protein. Acetyl phosphate is likely to affect the regulation of many targets, such as cyclic AMP (cAMP), and thus might constitute a global signal (McCleary et al. 1993). The required specificity is obtained by control of the phosphorylation of response regulators and, in some cases, by the highly specific control of the dephosphorylation of response regulators by the regulated phosphatase activities. Based on similarity with OmpR-EnvZ and PhoB-PhoR systems, which belong to the same subfamily as PhoP-PhoQ, we can hypothesize that PehS mediates both phosphorylation of PehR and dephosphorylation of P-PehR (Igo et al. 1989; Parkinson and Kofoid 1992; Gunn et al. 1996). Thus, unspecific phosphorylation of PehR, but not dephosphorylation may occur in the pehS mutant, causing the overproduction of phosphorylated PehR. The overproduction of the phosphorylated regulator may modulate expression of genes that are directly or indirectly connected with virulence. It is also possible that PehR is not the only response regulator that is phosphorylated by PehS and that the nonphosphorylated response regulator may also have a functional role. We cannot, however, rule out the possibility that some of the observed effects are due to allele copy number. It has been suggested that low concentration of phosphorylated regulator can cause activation of target gene transcription, while high concentration could cause the opposite reactionrepression of these genes (Stock et al. 1989; Parkinson 1993). This could explain why the pehR-pehS wild-type allele cloned into a high copy vector pBluescript could not restore the Peh phenotype of pehR and pehS mutants (data not shown) and the low copy plasmid pREM200 partly restored Peh activity. However, the results could also suggest that Peh activity is not the only cause for reduced virulence in the mutants.

The regulatory operon pehR-pehS encodes proteins that are members of a two-component regulatory family. We here demonstrate both structural and functional similarity of PehRPehS to the products of the $p h o P-p h o Q$ regulatory operon of $S$. typhimurium and E. coli. PhoP was clearly required for expression of pehA in E. coli and it appeared even to be required for $\mathrm{Ca}^{2+}$ controlled repression of pehA. Such repression of gene expression was described earlier for pehA in E. carotovora (Flego et al. 1997) and for a number of PhoP-PhoQ controlled genes in E. coli and S. typhimurium (García-Véscovi et al. 1996).

It is intriguing that in both $E$. coli and $S$. typhimurium phoP-phoQ controls production of more than 40 polypeptides (Miller and Mekalanos 1990; Kasahara et al. 1992). In $S$. typhimurium about $25 \%$ of these are involved in virulence. A functional phoP-phoQ operon is required for expression of an NSAP, survival within macrophages, resistance to antimicrobial peptides, and acid $\mathrm{pH}$, and is also involved in protein export. The $p h o P-p h o Q$ regulator system can be a repressor for some genes and activator for others. The phoP-phoQ modulated genes in $S$. typhimurium are induced under very different conditions and respond in different fashions to the same environmental stimuli such as starvation and rich media, acid $\mathrm{pH}$ and neutral $\mathrm{pH}$, and anaerobiosis and aerobiosis. Homologues of phoP-phoQ have been found in several bacteria species, including nonpathogens, indicating that the phoP-phoQ operon is not ex- 
clusively involved in virulence and that it probably plays a central role in the physiology of many Gram-negative bacteria (García-Véscovi et al. 1994; Pegues et al. 1995). Thus, the phoP-phoQ regulator system appears to be a central global regulator of many processes in bacteria, including virulence. This is clearly contrasted by the role of pehRpehS in E. carotovora subsp. carotovora, where we so far have only observed a specific reduction of pehA expression in the mutants. In addition, we have observed a slight upregulation of pelB expression in the mutant background (not shown). However, the extensive structural and functional similarity between $p e h R-p e h S$ and $p h o P-p h o Q$ suggests that even pehR-pehS could control several genes. Thus, it is feasible to assume that additional genes involved directly or indirectly in virulence could be regulated by pehR-pehS.

\section{MATERIALS AND METHODS}

\section{Bacterial strains and plasmids.}

The E. coli strain DH5 $\alpha$ (Hanahan 1983) was used for plasmid maintenance and DNA preparations. The E. carotovora subsp. carotovora wild-type strain SCC3193 (Pirhonen et al. 1988) and its mutant derivatives SCC1935 (pehR mutant), SCC4080 (pehA mutant) (Saarilahti et al. 1992) have been described. The strain SCC4194 (pehS mutant) was isolated in this study (see below). The E. coli strain MC4100 (Casadaban 1976) and its phoP mutant FS1002 have been described (Groisman et al. 1992). The $S$. typhimurium wild-type strain ATCC 14028s (Fields et al. 1986), its phoP mutant MS7953s, and phoQ mutant MS5996s have been described (Fields et al. 1989). The pBluescript IISK plasmid was purchased from Stratagene (La Jolla, CA) and the pMW118 from Eurogentec (Seraing,

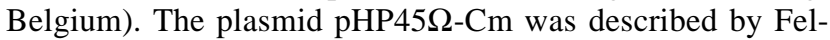
lay et al. (1987). The plasmid pHSK24 has been described by Saarilahti et al. (1990) and pHLU102 by Lång and Palva (1993). The plasmids pREM100, pREM200, pREM201, pREM202, and pDFL2 were constructed in this study (see below). Plasmid preparations were done with Qiagen plasmid kits (Qiagen, Hilden, Germany). Transfer of the plasmids was done by standard transformation technique $(E$. coli) or by electroporation (E. carotovora subsp. carotovora, $S$. typhimurium) with the Bio-Rad gene pulser (Bio-Rad Laboratories, Richmond, CA).

\section{Media, growth conditions, and chemicals.}

E. coli and S. typhimurium strains were grown in L medium (Miller 1972) at $37^{\circ} \mathrm{C}$ and E. carotovora subsp. carotovora strains at $28^{\circ} \mathrm{C}$. When necessary, appropriate antibiotics were added to medium at the following concentrations: chloramphenicol $(\mathrm{Cm})$, kanamycin $(\mathrm{Km})$, and tetracycline $(\mathrm{Tc})$ were added to media at $25 \mu \mathrm{g} \mathrm{ml}^{-1}$ and ampicillin (Ap) at $150 \mu \mathrm{g}$ $\mathrm{ml}^{-1}$. For NSAP assay the $S$. typhimurium strains were grown on phosphorus-free M121 salts medium (Torriani 1966) plates supplemented with $\mathrm{KH}_{2} \mathrm{PO}_{4}(50 \mathrm{mM})$, thiamin $\left(1 \mu \mathrm{g} \mathrm{ml}{ }^{-1}\right)$ and glucose $(0.4 \%)$ as a carbon substrate. E. carotovora subsp. carotovora were grown on M121 salts medium supplemented with $\mathrm{KH}_{2} \mathrm{PO}_{4}$ (either $50 \mathrm{mM}$ as excess or $0.1 \mathrm{mM}$ as limiting), casamino acids $(0.3 \%)$ and glycerol $(0.8 \%)$ as a carbon source. The restriction enzymes, Klenow fragment, T4 ligase, mung bean nuclease, multiprime DNA labeling kit, radiola- beled dATP, and L-methionine were from Amersham International (Buckinghamshire, UK). The DNA sequencing kit was from United States Biochemicals (Cleveland, OH). Synthetic oligonucleotides were purchased from Kebo Lab (Kebo, Stockholm) and Pharmacia Biotech (Uppsala, Sweden). The p-nitrophenyl phosphate (Sigma 104), $\alpha$-naphthyl phosphate, tetrazotized o-dianisidine, and polygalacturonic acid (PGA) (P-1879) were from Sigma Chemical (St. Louis, MO). 2Nitrophenyl- $\beta$-D-galactopyranoside was from Merck (Darmstadt, Germany).

\section{Cloning techniques and DNA sequencing.}

To clone the mutated pehR locus, chromosomal DNA of the mini-kan transposon (Way et al. 1984) mutant SCC1935 was cut by restriction enzymes PstI, EcoRI-XbaI, or SalI and ligated into pBluescript IISK digested with corresponding enzymes, followed by transformation to the E. coli strain DH5 $\alpha$. Mutated allele-containing clones were selected for the kanamycin resistance gene of the transposon. The 3.2-kb SalIEcoRI fragment was further subcloned to smaller fragments suitable for sequencing by the Sanger dideoxy-chain termination method. To sequence both strands, synthetic oligonucleotides designed from the completed sequence were used. For cloning the intact wild-type pehR-pehS alleles, the following primers were designed: 5' GGTACCAACCATTTCCAGCC TG 3' and 5' CTCGAGATTGAGCTGATAGAC 3'. PCR was performed with the proofreading Vent DNA polymerase (New England Biolabs, Beverly, MA) with wild-type SCC3193 chromosome as a template. The resulting $2.5-\mathrm{kb}$ fragment was ligated to EcoRV-digested pBluescript IIKS vector to create plasmid pREM100. For generation of pehS mutant, HindIIIdigested and blunted, 3.5-kb, Cm-specific interposon fragment of the plasmid pHP45- $\Omega$ was ligated with MluI-digested and blunted pREM100. Resulting plasmid pDFL6 was electroporated into the E. carotovora subsp. carotovora wild-type strain SCC3193. For marker exchange, SCC3193/pDFL6 was grown overnight in L medium with $\mathrm{Cm}$ selection and left standing at room temperature over two nights. Recombinants were selected on L-Cm plates and true marker exchange mutants were screened for by loss of the plasmid-encoded ampicillin resistance. The pehS mutant, named SCC4194, was purified and controlled by Southern analysis. For complementation the 2.5$\mathrm{kb}$ BamHI and HindIII fragment carrying pehR-pehS in pREM100 was transferred into corresponding sites of the low copy number plasmid pMW118, resulting in pREM200. To generate a mutant of the cloned pehR, pREM100 was digested with NdeI, the single-strand DNA overhangs removed by mung bean nuclease and the blunt ends ligated. The resulting plasmid pREM101 had lost the NdeI cleavage site. Sequencing of both strands showed that two nucleotides $\mathrm{T}$ and $\mathrm{A}$ (309th and 310th from ATG) were deleted, causing a frameshift in pehR. For complementation, the 2.5-kb BamHIHindIII fragment of pREM101, carrying the mutant allele of pehR but an intact pehS gene, was transferred into pMW118, resulting in pREM201. To generate the pehR ${ }^{+}$-pehS mutant clone (pREM202), the 859-bp MluI-SphI fragment was deleted from the pehS gene of pREM200. The pehA-lacZ transcriptional fusion pDFL2 (Flego et al 1997) was created by first inserting an 1.6-kb HindIII fragment of pHSK24, carrying the pehA promoter region, into the HindIII site of pBluescript and subsequently moving this promoter as an 
EcoRI-KpnI fragment to the corresponding sites upstream of the promoterless lacZ gene of pHLU102.

\section{Isolation of chromosomal DNA and total RNA, and South- ern and Northern hybridization.}

Chromosomal DNA of SCC3193 and SCC4194 was isolated as described by Sambrook et al. (1989). Total RNA was isolated by the RNeasy kit (Qiagen) according to the instructions given by the manufacturer. For Northern analysis, $5 \mu \mathrm{g}$ of total RNA was denatured in formamide and formaldehyde and separated by formaldehyde gel electrophoresis. The blotting onto nylon membranes (Hybond-N; Amersham International) and Southern and Northern hybridization were as described by Sambrook et al. (1989). The gene-specific probes were the 1.2-kb EcoRI fragment of pHSK24 for pehA and the 1.3-kb ClaI fragment of pREM100 for pehS. The probe fragments were labeled with ${ }^{32} \mathrm{P}$-dATP by random priming. The signals were visualized by autoradiography or by phosphorimager and the data were processed with the Image Quant program (Molecular Dynamics, Sunnyvale, CA).

\section{Assay procedures.}

The polygalacturonase (Peh) enzyme activity was measured and units defined as described by Pirhonen et al. (1991). The extracellular enzyme indicator plates were according to Pirhonen et al. (1993). The $\beta$-galactosidase activity was determined from samples immediately after collection as described by Miller (1972). The NSAP staining procedure was according to Kier et al. (1979). The S. typhimurium strains were grown on non-induced conditions to prevent background caused by low activity of acid hexose phosphatase and cyclic phosphodiesterase toward $\alpha$-naphthyl phosphate as a substrate (Weppelman et al. 1977). Phosphatase activity toward pnitrophenyl phosphate was determined as described by Brickman and Beckwith (1975).

\section{Assay of bacterial virulence.}

The virulence of SCC3193, SCC1935, SCC4194, and SCC4080 was tested on axenic tobacco seedlings (Nicotiana tabacum cv. Samsun) grown on MS medium (Murashige and Skoog 1962) supplemented with $2 \%$ sucrose on 24-well tissue culture plates. Bacteria were propagated overnight in $\mathrm{L}$ medium at $28^{\circ} \mathrm{C}$, diluted in $0.9 \% \mathrm{NaCl}$, and used to inoculate 3to 4-week-old axenic tobacco seedlings. Plasmid carrying strains were diluted in $0.9 \% \mathrm{NaCl}$ supplemented with ampicillin. The leaves were punctured by a needle and $1 \mu$ of bacterial suspension $\left(10^{4} \mathrm{CFU}\right)$ was applied to the damaged site on the leaf. One leaf per well was inoculated. After infection, the plants were incubated at $28^{\circ} \mathrm{C}$ in high humidity at light. The development of disease symptoms (tissue maceration) was followed up to $72 \mathrm{~h}$. Plants that exhibited clear tissue maceration in $72 \mathrm{~h}$ were scored as infected.

\section{ACKNOWLEDGMENTS}

We thank Eduardo Groisman and Mika Rehn for kindly providing us pho mutant strains of E. coli and S. typhimurium. Petri Luoma is thanked for invaluable help with the figures. This work was supported by SAREC, the Swedish Council for Forestry and Agricultural Research (SJFR), the Foundation in Memory of Oskar and Lili Lamm, the Academy of Finland, Biocentrum Helsinki, and the EU (contract no. ERBIC15-CT96-0908).

\section{LITERATURE CITED}

Andro, T., Chambost, J.-P., Kotoujansky, A., Cattaneo, J., Bertheau, Y., Barras, F., van Gijsegem, F., and Coleno, A. 1984. Mutants of Erwinia chrysanthemi defective in secretion of pectinase and cellulase. J. Bacteriol. 160:1199-1203.

Barras, F., van Gijsegem, F., and Chatterjee, A. K. 1994. Extracellular enzymes and pathogenesis of soft-rot Erwinia. Annu. Rev. Phytopathol. 32:201-234.

Beaulieu, C., Boccara, M., and Van Gijsegem, F. 1993. Pathogenic behavior of pectinase-defective Erwinia chrysanthemi mutants on different plants. Mol. Plant-Microbe Interact. 6:197-202.

Brickman, E., and Beckwith, J. 1975. Analysis of the regulation of Escherichia coli alkaline phosphatase synthesis using deletions and Fi80 transducing phages. J. Mol. Biol. 96:307-316.

Casadaban, M. J. 1976. Transposition and fusion of the lac genes to selected promoters in Escherichia coli using bacteriophage lambda and Mu. J. Mol. Biol. 104:541-555.

Chatterjee, A., Cui, Y., Liu, Y., Dumenyo, C. K., and Chatterjee, A. K. 1995. Inactivation of $r s m A$ leads to overproduction of extracellular pectinases, cellulases, and proteases in Erwinia carotovora subsp. carotovora in the absence of the starvation/cell density-sensing signal, $\mathrm{N}$-(3-oxoheanoyl)-L-homoserine lacton. Appl. Environ. Microbiol. 61: 1959-1967.

Collmer, A., and Keen, N. T. 1986. The role of pectic enzymes in plant pathogenesis. Annu. Rev. Phytopathol. 24:383-409.

Cui, Y., Chatterjee, A., Liu, Y., Dumenyo, C. K., and Chatterjee, A. K. 1995. Identification of a global repressor gene, rsmA, of Erwinia carotovora subsp. carotovora that controls extracellular enzymes, $N$ (3-oxohexanoyl)-L-homoserine lactone, and pathogenicity in softrotting Erwinia spp. J. Bacteriol. 177:5108-5115.

Eriksson, A. R. B., Andersson, R. A., Pirhonen, M., and Palva, E. T. 1998. Two-component regulators involved in the global control of virulence in Erwinia carotovora subsp. carotovora. Mol. PlantMicrobe Interact. 11:743-752.

Fellay, R., Frey, J., and Krisch, H. 1987. Interposon mutagenesis of soil and water bacteria: A family of DNA fragments designed for in vitro insertional mutagenesis of gram-negative bacteria. Gene 52:147-154.

Fields, P. I., Groisman, E. A., and Heffron, F. 1989. A Salmonella locus that controls resistance to microbicidal proteins from phagocytic cells. Science 243:1059-1062.

Fields, P. I., Swanson, R. V., Haidaris, C. G., and Heffron, F. 1986. Mutants of Salmonella typhimurium that cannot survive within the macrophage are avirulent. Proc. Natl. Acad. Sci. USA 83:5189-5193.

Flego, D., Pirhonen, M., Saarilahti, H., Palva, T. K., and Palva, E. T. 1997. Control of virulence gene expression by plant calcium in the phytopathogen Erwinia carotovora. Mol. Microbiol. 25:831-838.

García-Véscovi, E., Soncini, F. C., and Groisman, E. A. 1994. The role of the PhoP/PhoQ regulon in Salmonella virulence. Res. Microbiol. 145:473-480.

García-Véscovi, E., Soncini, F. C., and Groisman, E. A. 1996. $\mathrm{Mg}^{2+}$ as an extracellular signal: Environmental regulation of Salmonella virulence. Cell 84: 165-174.

Govantes, F., Andújar, E., and Santero, E. 1998. Mechanism of translational coupling in the nifLA operon of Klebsiella pneumoniae. EMBO J. 17:2368-2377.

Groisman, E. A., Heffron, F., and Solomon, F. 1992. Molecular genetic analysis of the Escherichia coli phoP locus. J. Bacteriol. 174:486491.

Gunn, J. S., Hohmann, E. L., and Miller, S. I. 1996. Transcriptional regulation of Salmonella virulence: A PhoQ periplasmic domain mutation results in increased net phosphotransfer to PhoP. J. Bacteriol. 178:6369-6373.

Hanahan, D. 1983. Studies on transformation of Escherichia coli with plasmids. J. Mol. Biol. 166:557-580.

Heikinheimo, R., Flego, D., Pirhonen, M., Karlsson, M.-B., Eriksson, A., Mäe, A., Kõiv, V., and Palva, E. T. 1995. Characterization of a novel pectate lyase from Erwinia carotovora subsp. carotovora. Mol. Plant-Microbe Interact. 8:207-217.

Hess, J. F., Bourret, R. B., and Simon, M. I. 1988. Histidine phosphorylation and phosphoryl group transfer in bacterial chemotaxis. Nature 336:139-143.

Igo, M. M., Ninfa, A. J., Stock, J. B., and Silhavy, T. J. 1989. Phosphorylation and dephosphorylation of a bacterial transcriptional activator 
by a transmembrane receptor. Genes Dev. 3:1725-1734.

Ji, J., Hugouvieux-Cotte-Pattat, N., and Robert-Baudouy, J. 1987. Use of $\mathrm{Mu}$-lac insertions to study the secretion of pectate lyases by Erwinia chrysanthemi. J. Gen. Microbiol. 133:793-802.

Jones, S., Yu, B., Bainton, N. J., Birdsall, M., Bycroft, B. W., Chhabra, S. R., Cox, A. J. R., Golby, P., Reeves, P. J., Stephans, S., Winson, M. K., Salmond, G. P. C., Stewart, G. S. A. B., and Williams, P. 1993. The lux autoinducer regulates the production of exoenzyme virulence determinants in Erwinia carotovora and Pseudomonas aeruginosa. EMBO J. 12:2477-2482.

Kasahara, M., Nakata, A., and Shinagawa, H. 1992. Molecular analysis of the Escherichia coli phoP-phoQ operon. J. Bacteriol. 174:492-498.

Kelemu, S., and Collmer, A. 1993. Erwinia chrysanthemi EC16 produces a second set of plant-inducible pectate lyase isozymes. Appl. Environ. Microbiol. 59:1756-1761.

Kier, L. D., Weppelman, R. M., and Ames, B. N. 1979. Regulation of nonspecific acid phosphatase in Salmonella: phoN and phoP genes. J. Bacteriol. 138:155-161.

Liu, Y., Cui, Y., Mukherjee, A., and Chatterjee, A. K. 1998. Characterization of a novel RNA regulator of Erwinia carotovora ssp. carotovora that controls production of extracellular enzymes and secondary metabolites. Mol. Microbiol. 29:219-234.

Liu, Y., Murata, H., Chatterjee, A., and Chatterjee, A. K. 1993. Characterization of a novel regulatory gene aepA that controls extracellular enzyme production in the phytopathogenic bacterium Erwinia carotovora subsp. carotovora. Mol. Plant-Microbe Interact. 6:299-308.

Lojkowska, E., Dorel, C., Reignault, P., Hugouvieux-Cotte-Pattat, N., and Robert-Baudouy, J. 1993. Use of GUS fusion to study the expression of Erwinia chrysanthemi pectinase genes during infection of potato tubers. Mol. Plant-Microbe Interact. 6:488-494.

Lång, H., and Palva, E. T. 1993. The ompS gene of Vibrio cholerae encodes a growth-phase-dependent maltoporin. Mol. Microbiol. 10:891901.

Mäe, A., Heikinheimo, R., and Palva, E. T. 1995. Structure and regulation of the Erwinia carotovora subspecies carotovora SCC3193 cellulase gene celV1 and the role of cellulase in phytopathogenicity. Mol. Gen. Genet. 247:17-26.

McCleary, W. R., Stock, J. B., and Ninfa, A. J. 1993. Is acetyl phosphate a global signal in Escherichia coli? J. Bacteriol. 175:2793-2798.

Miller, J. F., Mekalanos, J. J., and Falkow, S. 1989. Coordinate regulation and sensory transduction in the control of bacterial virulence. Science 243:916-922.

Miller, J. H. 1972. Experiments in Molecular Genetics. Cold Spring Harbor Laboratory, Cold Spring Harbor, NY. p. 466.

Miller, S. I., and Mekalanos, J. J. 1990. Constitutive expression of the PhoP regulon attenuates Salmonella virulence and survival within macrophages. J. Bacteriol. 172:2485-2490.

Mukherjee, A., Cui, Y., Liu, Y., Dumenyo, C. K., and Chatterjee, A. K. 1996. Global regulation in Erwinia species by Erwinia carotovora rsmA, a homologue of Escherichia coli csrA: Repression of secondary metabolites, pathogenicity and hypersensitive reaction. Microbiology 142:427-434

Murashige, T., and Skoog, F. 1962. A revised medium for rapid growth and bio assays with tobacco tissue cultures. Physiol. Plant. 15:473497.

Murata, H., Chatterjee, A., Liu, Y., and Chatterjee, A. K. 1994. Regulation of the production of extracellular pectinase, cellulase, and protease in the soft rot bacterium Erwinia carotovora subsp. carotovora: Evidence that aepH of E. carotovora subsp. carotovora 71 activates gene expression in E. carotovora subsp. carotovora, E. carotovora subsp. atroseptica, and Escherichia coli. Appl. Environ. Microbiol. 60:3150-3159.

Murata, H., McEvoy, J. L., Chatterjee, A., Collmer, A., and Chatterjee, A. K. 1991. Molecular cloning of an aepA gene that activates production of extracellular pectolytic, cellulolytic, and proteolytic enzymes in Erwinia carotovora subsp. carotovora. Mol. Plant-Microbe Interact. 4:239-246.

Parkinson, J. S. 1993. Signal transduction schemes of bacteria. Cell 73: 857-871.

Parkinson, J. S., and Kofoid, E. C. 1992. Communication modules in bacterial signaling proteins. Annu. Rev. Genet. 26:71-112.

Pegues, D. A., Hantman, M. J., Behlau, I., and Miller, S. I. 1995. PhoP/PhoQ transcriptional repression of Salmonella typhimurium invasion genes: Evidence for a role in protein secretion. Mol. Microbiol. 17:169-181.

Pérombelon, M. C. M., and Kelman, A. 1980. Ecology of the soft rot Erwinias. Annu. Rev. Phytopathol. 18:361-387.

Pirhonen, M., Flego, D., Heikinheimo, R., and Palva, E. T. 1993. A small diffusible signal molecule is responsible for the global control of virulence and exoenzyme production in the plant pathogen Erwinia carotovora. EMBO J. 12:2467-2476.

Pirhonen, M., Heino, P., Helander, I., Harju, P., and Palva, E. T. 1988. Bacteriophage T4 resistant mutants of the plant pathogen Erwinia carotovora. Microb. Pathog. 4:359-367.

Pirhonen, M., Saarilahti, H., Karlsson, M.-B., and Palva, E. T. 1991. Identification of pathogenicity determinants of Erwinia carotovora subsp. carotovora by transposon mutagenesis. Mol. Plant-Microbe Interact. 4:276-283.

Saarilahti, H. T., Heino, P., Pakkanen, R., Kalkkinen, N., Palva, I., and Palva, E. T. 1990. Structural analysis of the pehA gene and characterization of its protein product, endopolygalacturonase, of Erwinia carotovora subspecies carotovora. Mol. Microbiol. 4:1037-1044.

Saarilahti, H. T., Pirhonen, M., Karlsson, M.-B., Flego, D., and Palva, E. T. 1992. Expression of pehA-bla gene fusions in Erwinia carotovora subsp. carotovora and isolation of regulatory mutants affecting polygalacturonase production. Mol. Gen. Genet. 234:81-88.

Sambrook, J., Fritsch, E. F., and Maniatis, T. A. 1989. Molecular Cloning: A Laboratory Manual. 2nd ed. Cold Spring Harbor Laboratory, Cold Spring Harbor, NY.

Soncini, F. C., García-Véscovi, E., and Groisman, E. A. 1995. Transcriptional autoregulation of the Salmonella typhimurium phoPQ operon. J. Bacteriol. 177:4364-4371.

Stock, J. B., Ninfa, A. J., and Stock, A. M. 1989. Protein phosphorylation and regulation of adaptive responses in bacteria. Microbiol. Rev. 53:450-490.

Thurn, K. K., and Chatterjee, A. K. 1985. Single-site chromosomal Tn5 insertions affect the export of pectolytic and cellulolytic enzymes in Erwinia chrysanthemi EC16. Appl. Environ. Microbiol. 50:894-898.

Torriani, A. 1966. Alkaline phosphatase from Escherichia coli. Pages 224-235 in: Procedures in Nucleic Acid Research. G. C. Cantoni and R. Davies, eds. Harper \& Row, New York.

Way, J. C., Davis, M. A., Morisato, D., Roberts, D. E., and Kleckner, N. 1984. New Tn10 derivatives for transposon mutagenesis and for construction of lacZ fusions by transposition. Gene 32:369-379.

Weiss, V., and Magasanik, B. 1988. Phosphorylation of nitrogen regulator I $\left(\mathrm{NR}_{\mathrm{I}}\right)$ of Escherichia coli. Proc. Natl. Acad. Sci. USA 85:89198923.

Weppelman, R., Kier, L. D., and Ames, B. N. 1977. Properties of two phosphatases and a cyclic phosphodiesterase of Salmonella typhimurium. J. Bacteriol. 130:411-419. 